\title{
Coronavirus Disease 2019: The Role of the Fibrinolytic System from Transmission to Organ Injury and Sequelae
}

\author{
Hau C. Kwaan, MD, FRCP ${ }^{1}$ \\ ${ }^{1}$ Division of Hematology-Oncology, Department of Medicine, Feinberg \\ School of Medicine, Northwestern University, Chicago, Illinois \\ Semin Thromb Hemost 2020;46:841-844.
}

\begin{abstract}
Address for correspondence Hau C. Kwaan, MD, FRCP, Division of Hematology-Oncology, Department of Medicine, Feinberg School of Medicine, Northwestern University, Olson Pavilion, 710 North Fairbanks Court, Chicago, IL 60611 (e-mail: h-kwaan@northwestern.edu).
\end{abstract}

An initial cluster of severe viral pneumonia was discovered in early December 2019 in Wuhan, China. It was found to be caused by a newly identified coronavirus, later named by the World Health Organization and the Coronavirus Study Group of the International Committee as severe acute respiratory syndrome coronavirus 2 (SARS-CoV-2) and the disease as coronavirus disease 2019 (COVID-19). ${ }^{1-4}$ The disease rapidly spread globally and was then declared as a pandemic. The most notable characteristic of SARS-CoV-2 is its high infectivity. As a result, much attention has been paid to its mode of transmission. The major route of infection is the binding of the spike protein of the virus to its natural receptor angiotensin-converting enzyme (ACE 2) on the surface of the host cells. ${ }^{2}$ ACE2 is present in tissues and is particularly abundantly expressed in the lung in the alveolar (type II) cells. This is clinically correlated as the lung is the major organ affected by the viral infection, leading to acute respiratory failure and acute respiratory distress syndrome (ARDS). Many aspects of COVID-19 are similar to those seen in the SARS and in the Middle East respiratory syndrome (MERS), ${ }^{5,6}$ including ACE2 being the receptor for the virus. ${ }^{7}$ Impaired fibrinolysis was observed in post-SARS complications. ${ }^{8,9}$ Impairedfibrinoly$\operatorname{sis}^{10,11}$ is present in pneumonia and acute lung injuries; accordingly, this commentary is devoted to reviewing evidence for possible involvement of the fibrinolytic system in transmission, pulmonary complications, and sequelae of COVID-19. Several possible drug targets that alter the activity of components of the fibrinolytic system are also discussed.

\section{Transmission}

One common characteristic that SARS-CoV-2 shares with SARS-CoV and MERS-CoV is its high infectivity, which gives the propensity to spread rapidly through the population. The spike protein on the viral envelop attaches to ACE2 on the surface of the host cells ${ }^{12-14}$ (-Fig. 1). ACE2 is an integral component of the renin-angiotensin-aldosterone system (RAAS). ${ }^{15}$ RAAS regulates blood pressure and aldosterone secretion. ${ }^{15-17}$ It is present in both circulation and tissues, ${ }^{18}$ particularly in the kidney, heart, and blood vessels. As shown in -Fig. 1, the plasma protein angiotensinogen is hydrolyzed by an aspartic protease renin in the kidney to angiotensin I. Angiotensin I is then converted to angiotensin II by ACE. Angiotensin II is further cleaved to angiotensin 1-7 and catalyzed by ACE2, a homolog of ACE. ${ }^{19}$ ACE2 is present in lung, kidney, heart, gastrointestinal system, and lymphocytes, and expressed on cell membranes. ACE2 acts as the receptor for SARS-CoV-2 as well as for other coronaviruses such as SARS$\mathrm{COV}^{20-22}$ ACE2 is abundant in type II alveolar cells and thus renders the lung highly susceptible to the attachment of SARS$\mathrm{CoV}-2$. Following binding of the virus, ACE2 is downregulated, leaving angiotensin II in excess. Angiotensin II binds to another receptor, causing lung injury. ${ }^{23,24}$ Our understanding of the role of the RAAS system in COVID-19 leads to the potential use of inhibitors of ACE and of angiotensin receptor blockers in the treatment of COVID-19. ${ }^{14}$

Components of the fibrinolytic system are also regulated by RAAS. ${ }^{25}$ Angiotensin II induces the expression of plasminogen activator inhibitor-1 (PAI-1) in the endothelial cells. ${ }^{26}$ An ACE inhibitor quinapril was shown to lower PAI-1 level in healthy subjects, ${ }^{27,28}$ whereas another inhibitor of ACE, ramipril, was found to lower the circulating PAI-1 level in patients with acute myocardial infarction. ${ }^{29}$ In healthy subjects, the status of fibrinolysis in the endothelium are kept in balance between tissue plasminogen activator (tPA) and PAI-1. As ACE is downregulated following the attachment of SARS-CoV-2, this balance is shifted to an excess of uncleaved angiotensin II, which, in turn, increases PAI-1 (- Fig. 1). Another component of the fibrinolytic system, tPA, is upregulated by the kinin- published online May 9, 2020
Issue Theme Maintaining Hemostasis and Preventing Thrombosis in COVID-19 -Part I; Guest Editors: Emmanuel J. Favaloro, PhD, FFSc (RCPA), and Giuseppi Lippi, MD.
Copyright $\odot 2020$ by Thieme Medical Publishers, Inc., 333 Seventh Avenue, New York, NY 10001, USA. Tel: +1(212) 760-0888.
DOI https://doi.org/ 10.1055/s-0040-1709996. ISSN 0094-6176. 


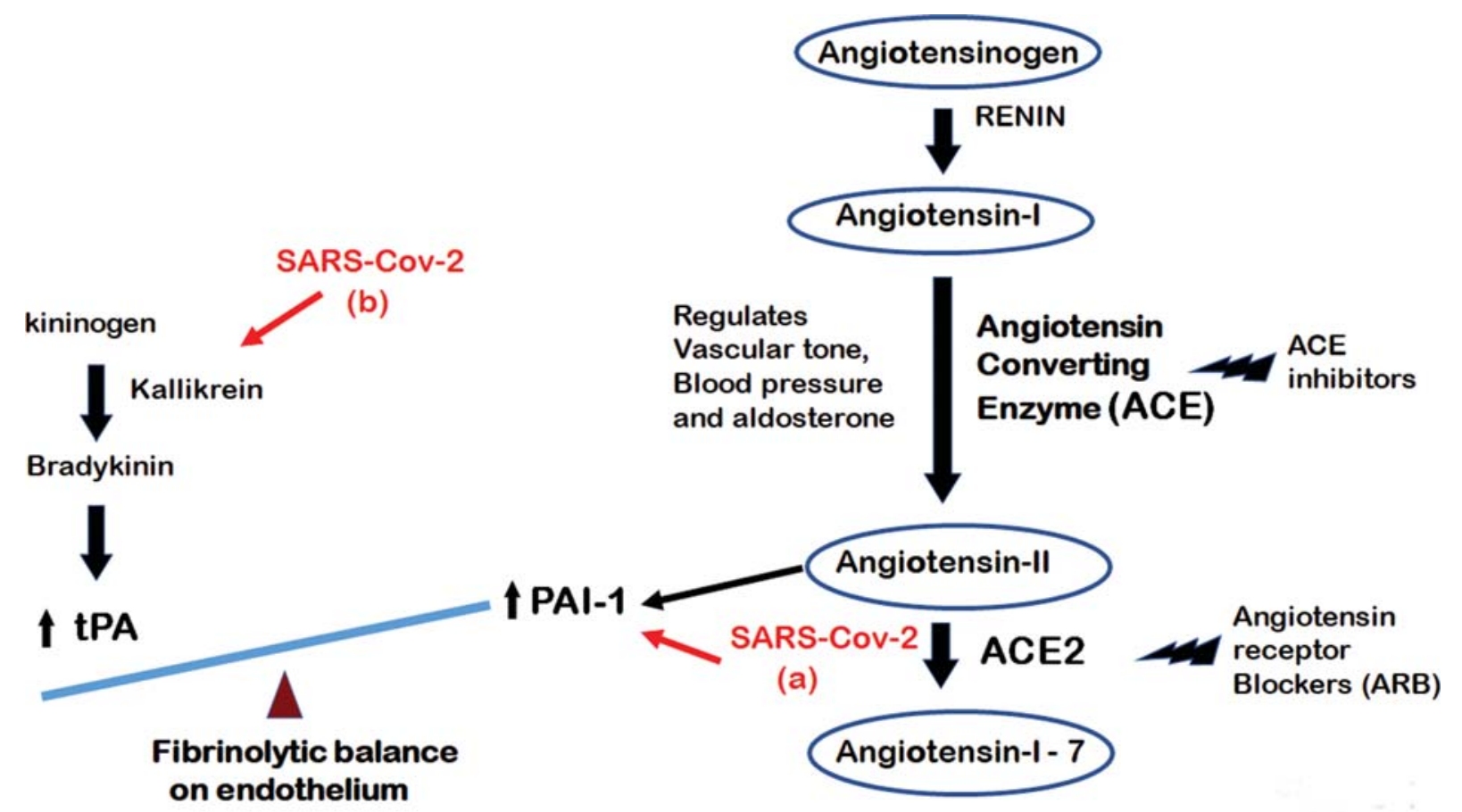

Fig.1 Effect of SARS-CoV-2 on the fibrinolytic balance of the endothelium through its actions on the renin-angiotensin-aldosterone system. By binding to ACE2, angiotensin II is prevented from breaking down to angiotensin 1-7 (a). The accumulated excess of angiotensin II enhances a greater expression of PAI-1 in the endothelium. SARS-CoV-2 evokes an acute inflammatory response with increase in bradykinin, which induces tPA expression in the endothelium, but insufficient to counterbalance the PAI-1 (b). ARB, angiotensin receptor blocker; ACE2, angiotensinconverting enzyme 2; PAI-1, plasminogen activator inhibitor-1; SARS-CoV-2, severe acute respiratory syndrome coronavirus 2; tPA, tissue plasminogen activator.

bradykinin pathway. ${ }^{30}$ The severe acute inflammatory response in COVID-19, with increased bradykinin, would favor increased tPA but is not sufficient to counterbalance the effect of increased PAI-1.

The result of high PAI-1 in the prothrombotic state in the lung may thus explain the unresolved fibrin deposits in the alveoli, which is a dominant feature of ARDS. The results of a clinical trial of tPA (discussed in the next section) will be crucial in supporting this concept. An alternate therapeutic approach is the use of inhibitor against PAI-1.

\section{Lung Pathology}

The proteolytic enzyme plasmin is formed by the activation of its precursor plasminogen by tPA and urokinase-type plasminogen activator (uPA). tPA is involved in the regulation of breakdown of fibrin and in neurologic functions, whereas uPA participates in many physiological and pathological processes including acute inflammation, wound healing, and tissue repair, as well as tumor growth and metastasis. uPA and plasmin are both activators of latent metalloproteinases in extracellular matrix remodeling, ${ }^{31}$ along with their respective regulatory protein networks. ${ }^{32,33}$ Both uPA and tPA are inhibited by PAI-1. During the acute injury in severe pneumonia, the virus attaches to the alveolar cells (as discussed above) and causes acute inflammatory response with exudation of fibrinogen into the alveola with fibrin and hyaline membrane formation. These changes are shown in both SARS ${ }^{31,34}$ and COVID-19. ${ }^{35-37}$ As the disease progresses to ARDS, more fibrin and fluid fill the alveolar spaces with perialveolar capillaries blocked by microthrombi. ${ }^{38}$ The increased presence of uPA was also demonstrated in vitro in human lung-derived epithelial cells (A549). ${ }^{31} \mathrm{uPA}$ is bound to its receptor (UPAR) on the cell surface, forming a UPA/uPAR complex, which effectively enhances the ability to activate plasminogen to plasmin (-Fig. 2). In the lungs of experimental animals and in human bronchial lavage, there is also increased PAI-1. This inhibitor keeps in check the excessive activity of uPA and prevents its further deterioration into intra-alveolar hemorrhage. On the other hand, overexpression of PAI-1 and other inhibitors of plasmin, such as antiplasmin, will result in a poor resolution of alveolar lesions and increase the risk of fibrosis. PAI-1 is well known to promote tissue fibrosis in pathological healing in many disorders. ${ }^{39,40}$ There is thus a delicate balance between excessive fibrinolysis, which increases the risk of intraalveolar hemorrhage, and excessive PAI-1, which ultimately fosters fibrosis. As antifibrinolytic agents such as tranexamic acid are available, the lung lesions can thus be a suitable therapeutic target. On the other hand, the lung has a high content of tissue factor; thus, conditions with lung injury are prothrombotic. Fibrinolytic therapy with uPA, streptokinase, and TPA had been used in the past for ARDS. ${ }^{41,42}$ It has also been proposed that therapeutic tPA may be used in selected patients with COVID-19 with severe ARDS. ${ }^{43}$ Ongoing clinical trials are going to verify this concept. 


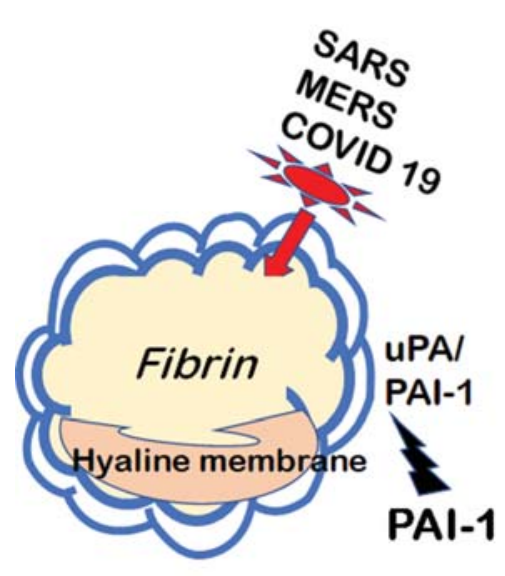

A. ARDS
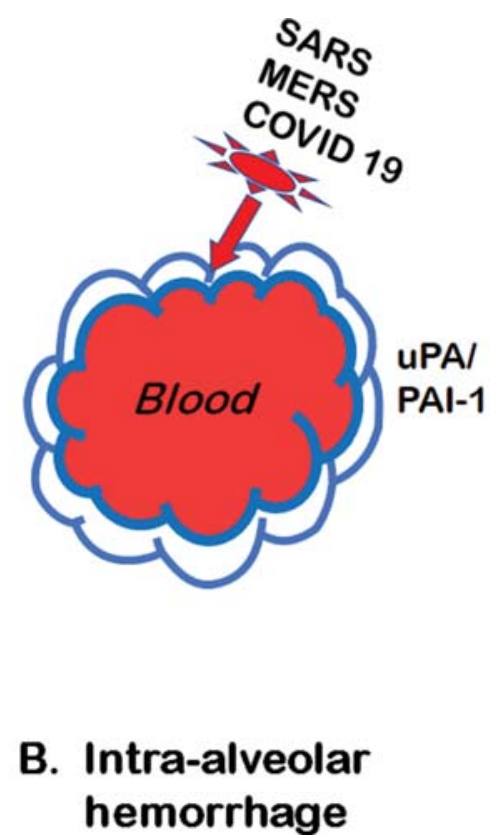

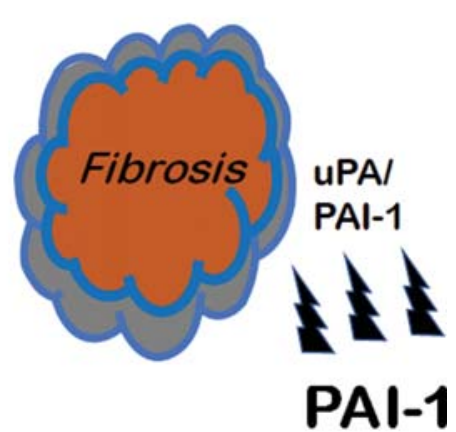

C. Pulmonary
fibrosis

Fig. 2 Different scenarios in the pulmonary alveoli in the pulmonary lesions seen in the acute respiratory syndromes of SARS, MERS, and COVID19. (A) ARDS occurs with exudation of fluid with fibrin and hyaline membrane formation as fibrinolysis by uPA/uPAR is inhibited by PAI-1 and fails to clear the fibrin. (B) Excessive fibrinolysis with a low PAI-1 response results in intra-alveolar hemorrhage. (C) Excessive PAI-1 increases the risk of resolution by fibrosis. ARDS, Acute respiratory distress syndrome; COVID-19, coronavirus disease 2019; MERS, Middle East respiratory syndrome; PAI-1, plasminogen activator inhibitor-1; SARS-CoV-2, severe acute respiratory syndrome coronavirus 2; uPA, urokinase-type plasminogen activator; uPAR, urokinase plasminogen activator receptor.

In conclusion, the large number of patients infected by the SAR-CoV-2 virus during the current epidemic brings a challenge to many. Many aspects of the pathology of COVID-19 are similar to those seen in SARS and MERS, including the involvement of several components of the fibrinolytic system. This provides an opportunity to target specific sites of the fibrinolytic system by either enhancing fibrinolysis or inhibiting PAI-1.

Conflict of Interest

The author has no conflict of interest to report.

\section{References}

1 Guan WJ, Liang WH, Zhao Y, et al; China Medical Treatment Expert Group for Covid-19. Comorbidity and its impact on 1590 patients with Covid-19 in China: a nationwide analysis. Eur Respir J 2020: 2000547

2 Guo YR, Cao QD, Hong ZS, et al. The origin, transmission and clinical therapies on coronavirus disease 2019 (COVID-19) outbreak - an update on the status. Mil Med Res 2020;7 (01):11

3 Zhou P, Yang XL, Wang XG, et al. A pneumonia outbreak associated with a new coronavirus of probable bat origin. Nature 2020;579 (7798):270-273

4 Guan WJ, Ni ZY, Hu Y, et al; China Medical Treatment Expert Group for Covid-19. Clinical characteristics of coronavirus disease 2019 in China. N Engl J Med 2020 (e-pub ahead of print) . Doi: 10.1056/NEJMoa2002032

5 Yin Y, Wunderink RG. MERS, SARS and other coronaviruses as causes of pneumonia. Respirology 2018;23(02):130-137

6 Lau YL, Peiris JS. Pathogenesis of severe acute respiratory syndrome. Curr Opin Immunol 2005;17(04):404-410
7 Li W, Zhang C, Sui J, et al. Receptor and viral determinants of SARScoronavirus adaptation to human ACE2. EMBO J 2005;24(08): 1634-1643

8 Sun W, Li ZR, Shi ZC, Zhang NF, Zhang YC. Changes in coagulation and fibrinolysis of post-SARS osteonecrosis in a Chinese population. Int Orthop 2006;30(03):143-146

9 Sun W, Li Z, Shi Z, et al. Relationship between post-SARS osteonecrosis and PAI-1 4G/5G gene polymorphisms. Eur J Orthop Surg Traumatol 2014;24(04):525-529

10 Idell S. Coagulation, fibrinolysis, and fibrin deposition in acute lung injury. Crit Care Med 2003;31(04):S213-S220

11 Wygrecka M, Jablonska E, Guenther A, Preissner KT, Markart P. Current view on alveolar coagulation and fibrinolysis in acute inflammatory and chronic interstitial lung diseases. Thromb Haemost 2008;99(03):494-501

12 Sun ML, Yang JM, Sun YP, Su GH. Inhibitors of RAS might be a good choice for the therapy of COVID-19 pneumonia [in Chinese]. Zhonghua Jie He He Hu Xi Za Zhi 2020;43(03):219-222

13 Dzau VJ, Bernstein K, Celermajer D, et al; Working Group on Tissue Angiotensin-converting enzyme, International Society of Cardiovascular Pharmacotherapy. The relevance of tissue angiotensinconverting enzyme: manifestations in mechanistic and endpoint data. Am J Cardiol 2001;88(9A:1L-20L

14 Vaduganathan M, Vardeny O, Michel T, McMurray JJV, Pfeffer MA, Solomon SD. Renin-angiotensin-aldosterone system inhibitors in patients with Covid-19. N Engl J Med 2020;382: In press

15 Tikellis C, Thomas MC. Angiotensin-converting enzyme 2 (ACE2) is a key modulator of the renin angiotensin system in health and disease. Int J Pept 2012;2012:256294

16 Ferrario CM. The renin-angiotensin system: importance in physiology and pathology.J Cardiovasc Pharmacol 1990;15(Suppl 3):S1-S5

17 Dzau VJ. Significance of the vascular renin-angiotensin pathway. Hypertension 1986;8(07):553-559

18 Dzau VJ, Hirsch AT. Emerging role of the tissue renin-angiotensin systems in congestive heart failure. Eur Heart J 1990;11(Suppl B ):65-71 
19 Donoghue M, Hsieh F, Baronas E, et al. A novel angiotensinconverting enzyme-related carboxypeptidase (ACE2) converts angiotensin I to angiotensin 1-9. Circ Res 2000;87(05):E1-E9

20 Jia HP, Look DC, Shi L, et al. ACE2 receptor expression and severe acute respiratory syndrome coronavirus infection depend on differentiation of human airway epithelia. J Virol 2005;79(23):14614-14621

21 Wan Y, Shang J, Graham R, Baric RS, Li F. Receptor recognition by novel coronavirus from Wuhan: an analysis based on decade-long structural studies of SARS. J Virol 2020;94(07): e00127-20

22 Li W, Moore MJ, Vasilieva N, et al. Angiotensin-converting enzyme 2 is a functional receptor for the SARS coronavirus. Nature 2003; 426(6965):450-454

23 Kuba K, Imai Y, Rao S, et al. A crucial role of angiotensin converting enzyme 2 (ACE2) in SARS coronavirus-induced lung injury. Nat Med 2005;11(08):875-879

24 Dijkman R, Jebbink MF, Deijs M, et al. Replication-dependent downregulation of cellular angiotensin-converting enzyme 2 protein expression by human coronavirus NL63. J Gen Virol 2012;93(Pt 9):1924-1929

25 Vaughan DE. Angiotensin, fibrinolysis, and vascular homeostasis. Am J Cardiol 2001;87(8A):18C-24C

26 Vaughan DE, Lazos SA, Tong K. Angiotensin II regulates the expression of plasminogen activator inhibitor-1 in cultured endothelial cells. A potential link between the renin-angiotensin system and thrombosis. J Clin Invest 1995;95(03): 995-1001

27 Brown NJ, Agirbasli MA, Williams GH, Litchfield WR, Vaughan DE. Effect of activation and inhibition of the renin-angiotensin system on plasma PAI-1. Hypertension 1998;32(06):965-971

28 Brown NJ, Kim KS, Chen YQ et al. Synergistic effect of adrenal steroids and angiotensin II on plasminogen activator inhibitor-1 production. J Clin Endocrinol Metab 2000;85(01):336-344

29 Vaughan DE, Rouleau JL, Ridker PM, Arnold JM, Menapace FJ, Pfeffer MA; HEART Study Investigators. Effects of ramipril on plasma fibrinolytic balance in patients with acute anterior myocardial infarction. Circulation 1997;96(02):442-447

30 Brown NJ, Nadeau JH, Vaughan DE. Selective stimulation of tissuetype plasminogen activator (t-PA) in vivo by infusion of bradykinin. Thromb Haemost 1997;77(03):522-525
31 Hattori N, Sisson TH, Xu Y, Desai TJ, Simon RH. Participation of urokinase-type plasminogen activator receptor in the clearance of fibrin from the lung. Am J Physiol 1999;277(03):L573-L579

32 García-Alvarez J, Ramirez R, Sampieri CL, et al. Membrane typematrix metalloproteinases in idiopathic pulmonary fibrosis. Sarcoidosis Vasc Diffuse Lung Dis 2006;23(01):13-21

33 Pardo A, Selman M. Matrix metalloproteases in aberrant fibrotic tissue remodeling. Proc Am Thorac Soc 2006;3(04):383-388

34 Gralinski LE, Bankhead A III, Jeng S, et al. Mechanisms of severe acute respiratory syndrome coronavirus-induced acute lung injury. MBio 2013;4(04):4

35 Yao XH, Li TY, He ZC, et al. A pathological report of three COVID-19 cases by minimally invasive autopsies [in Chinese]. Zhonghua Bing Li Xue Za Zhi 2020;49(00):E009

36 Tian S, Hu W, Niu L, Liu H, Xu H, Xiao SY. Pulmonary pathology of early-phase 2019 novel coronavirus (COVID-19) pneumonia in two patients with lung cancer. J Thorac Oncol 2020 (e-pub ahead of print) . Doi: S1556-0864(20)30132-5

37 Yang X, Yu Y, Xu J, et al. Clinical course and outcomes of critically ill patients with SARS-CoV-2 pneumonia in Wuhan, China: a single-centered, retrospective, observational study. Lancet Respir Med 2020 (e-pub ahead of print) . Doi: S2213-2600(20)30079-5

38 Ware LB. Pathophysiology of acute lung injury and the acute respiratory distress syndrome. Semin Respir Crit Care Med 2006; 27(04):337-349

39 Ghosh AK, Vaughan DE. PAI-1 in tissue fibrosis. J Cell Physiol 2012; 227(02):493-507

40 Flevaris $\mathrm{P}$, Vaughan $\mathrm{D}$. The role of plasminogen activator inhibitor type-1 in fibrosis. Semin Thromb Hemost 2017;43(02):169-177

41 Hardaway RM, Harke H, Tyroch AH, Williams CH, Vazquez Y, Krause GF. Treatment of severe acute respiratory distress syndrome: a final report on a phase I study. Am Surg 2001;67(04):377-382

42 Hardaway RM, Williams CH, Marvasti M, et al. Prevention of adult respiratory distress syndrome with plasminogen activator in pigs. Crit Care Med 1990;18(12):1413-1418

43 Moore HB, Barrett CD, Moore EE, et al. Is there a role for tissue plasminogen activator (tPA) as a novel treatment for refractory COVID-19 associated acute respiratory distress syndrome (ARDS)? J Trauma Acute Care Surg 2020 (e-pub ahead of print) . Doi: $10.1097 /$ TA.0000000000002694 